\title{
Interpreting Museums as Cultural Metaphors Michael Sikes
}

For anyone concerned with the educative role of museums, the question of what kinds of information the museum communicates is of basic importance. There is a body of research concerning the ways in which museums communicate, at least on a formal level through exhibits and programs. However, there is a deeper level at which each museum communicates, a level at which the site, the building, the people who work in it, and the objects that are exhibited there engage the visitor in a multilayered transference of meaning.

One of the ways in which a complex system of meaning is rapidly transferred is via metaphor. This is a process by which we understand the unfamiliar by comparing it to the familiar, and grasp the abstract by comparing it to the concrete.

The function and power of metaphor was known as early as the time of Aristotle, and metaphor was respected as a useful tool for the communication of knowledge well into the Middle Ages. This respect diminished following the Renaissance, until by the twentieth century metaphor was widely considered a mere linguistic ornamentation, incapable of conveying any meaning that could not be conveyed equally well, and more directly, through literal statement (Johnson, 1981).

However, metaphor has enjoyed a renaissance of its own in recent decades, with a seminal article by Black (1981), along with other influential works by Richards (1981) and Langer (1957), all of whom helped to establish that metaphor is capable of communicating original truth in a way that is uniquely powerful. Metaphor is now often regarded as essential to speech and even to thought (Lakoff and Turner, 1989), a cognitive structure whose power adheres in a swift transfer of vast fields or schemas of meaning from one conceptual domain to another. Metaphor strongly shapes our ability to conceive reality (Sarup, 1989).

Rather than only being spoken or written, metaphor can function within any notational system. For example, works of art have metaphoric properties (Anderson, 1989; Feinstein, 1982; Langer, 1957). But in these visual metaphors the referents (that is, the objects or concepts to which they refer) are often missing or implied (Johnson, 1981).

It seems only a small conceptual step to infer that the institutions built to house and display works of art have similar metaphoric properties, that they are in fact extended metaphors or allegories, representing the deep beliefs of 
civilization and society. This concept is not totally new. Levin (19), for example, stated that contemporary museums are either "temples" or "showrooms." Through the use of these two metaphors he meant that museums could be placed into two categories, depending on a complex set of qualities, that combine to present an austere, exalted image or a commercial, inviting image to the potential visitor.

However, it is likely that museums represent even more abstract qualities, and refer to even vaster conceptual fields than Levin's typology suggests. For, as in the case of other non-linguistic metaphors, the referential meaning of the museum metaphor has been obscured in time. It is as if the two terms of the metaphoric proposition have become disjointed. It is this researcher's idea that such institutions are "blind metaphors," because they refer to hidden or invisible referents. To discover these referents is the challenge involved in understanding the museum as a cultural metaphor.

What is that referent or set of referents? To what in human experience does the museum seem to relate? To what value system, set of beliefs, or underlying world view? In asking these questions, we may find that from an initial attempt to understand changes in the contemporary museum through their relationship to ancient historic trends and structures, we may come to understand the ancient trends and structures through their relationship to museums, perhaps an even more important attainment.

One perspective on the metaphoric possibilities of museums is offered by Campbell (1986), who noted that metaphor is strongly connected to mythic structures of human experience. Campbell suggests that human experience can be separated into cultural monads, or great traditions, whose existence would imply that museums function metaphorically at more than one level, and that the different levels are tied to different mythic structures and the attendant meanings therein.

For example, art museums might relate metaphorically to at least two such mythic structures. One structure is that of capitalism and its associated forms, which first arose with the trading class, the burghers, and the bourgeoisie in Europe in the second millennium (Dewey, 1934). The second is the longer mythic structure of civilized society itself, with its attendant structures of sacred and secular art. It is likely that these mythic structures are in constant tension and flux. Further, it is likely that differing activities in and attitudes toward museums, as well as the changes that are taking place in museums, unconsciously reflect this tension and flux.

This power to represent a much vaster conceptual realm is not limited to art museums. Postman (1990) observed that science museums metaphorically communicate the popular perception that technology can solve all of our social problems, which in turn represents the modern mythic structure of rationalism and empiricism. Moreover, a historical museum

Working Papers in Art Education 1991 
serves as a metaphor for the human need to exert control over historic time (MacDonald and Silverstone, 1990).

Another possible perspective on the metaphoric and mythic relations of museums comes from postmodernist philosophers such as Lyotard, who notes that many of the grand traditions or "metanarratives" of history have lost their power over contemporary institutions, casting the later adrift in a vast shift of informational collection and use (Sarup, 1989). This would explain much change in contemporary museums.

Examples of the tendency of museums to represent abstract qualities metaphorically abound: Many of the museums of Washington, D.C. symbolize America's cultural maturity and cultural independence from Europe. On a much smaller scale, the typical museum in a smaller American city may reflect imbedded concepts of local civic pride. Moreover, a museum may have a split personality, referring to two traditions simultaneously, such as the local museum that collects ancient Greek objects, thus serving as a metaphor of a much longer tradition, that of Western civilization itself. This is an example of the relationship of two monads or mythic structures mentioned above.

In another vein, three Florida museums, the Dali Museum, the Appleton, and the Ringling speak metaphorically about the tastes and the times of individual collectors; yet the Heard Museum in Phoenix, also the product of a family vision, overlays this statement with reference to another tradition that reaches back into a non-European past.

But is there something that all museums represent, something that is characteristic of all people? We know that some cultural artifacts mirror fundamental structural qualities of all people: for example, all musical instruments seem to correspond to the general range of human hearing, and most visual art media reflect our ability to perceive only the visible spectrum of light. In the same way, is it not probable that the structure of museums reflects certain necessarily human cognitive processes and social structures? If so, what does the museum mirror, what do its reflections show us?

At one level, they show us where we have been, by reaching across layers of time to gather the things that people have thought worth preserving, and by using these objects to represent traditions and experiences both great and obscure.

Perhaps more significantly, these reflections illuminate who and what we are. They show us that people have ideas and experiences that they choose to record or express through the creation of objects; and that people also have a need to create forms that possess no practical significance, but exist only for their own sake. They reveal that people need to see and understand the world through other persons' eyes; and that people also need to preserve and experience certain objects because of their beauty, their

Working Papers in Art Education 1991 
rarity, or the skill evinced in their making. They reveal that people gather socially to celebrate the possession of all of these qualities. These reflections show us much about the basic human condition, and about the human view of that condition (Postman, 1990). In short the museum is an immensely complex metaphorical statement about the nature of life on earth.

\section{Research Grounded in the Museum Phenomenon}

In view of this dynamic function as cultural metaphor, it is imperative to form some basic knowledge or ground structure for understanding the workings of the museum. Thus, this researcher proposes the following position which is grounded in his critical acquaintance with art museums: The modern art museum stands in metaphoric relationship to sociocultural and economic structures, not only of modern Western society and of world civilization, but of local people and communities. It is likely that intensive study of the attributes of a museum, including sampling of the perceptions of those who participate in the museum ritual, would portray more clearly the form and structure of the metaphor, and the specific social structures which it predicates.

This researcher intends to test the credibility and usefulness of this theory through intensive research in the museum setting. This research will utilize naturalistic methods of inquiry, which are more suited for discerning the "deep structure" of social or cultural phenomena (Patton, 1990). Such methods typically include personal observation of and participation in the activities of the institution and extensive investigation of the perceptions of participants, including museum visitors, museum professionals, and others close to the museum, through interview, focus groups, and conversations. A third key component of this research will entail personal critical analysis of a specific museum as a holistic, aesthetic entity.

\section{Discerning the Deep Structure: Multiple Perspectives on and Practical Applications of the Museum Metaphor}

The questions that might be asked in the research process vary across a wide range and yet share a common focus. For example, the researcher might ask civic leaders who helped to plan a museum, "What is the message that you wanted to convey by placing a museum in this city? What did you expect it to tell people about your aspirations, perceptions, and progress as a community?" For the administrators and board members of existing museums, the questions might be, "What is the meaning and relevance of this institution? What experiences is it providing, and for whom else might it provide meaning?" The researcher might ask the curator, "What is the symbolic meaning of the objects that you collect, and how is that meaning shaped through their display?"

The museum educator has a central role in interpreting the meaning of the museum to its visitors, and this interpretation involves not only the

Working Papers in Art Education 1991 
separate components, the collections and exhibits, but the entire holistic phenomenon of the museum experience. The researcher might inquire of the educator, "What kinds of ideas and meanings do you wish to communicate to the visitor, about not only the objects in the museum, but the museum itself?" An even more basic question might be, "What kinds of experiences and meanings does the visitor already have, that may influence what he or she is likely to learn?" And finally, the educator might be asked "What other kinds of worthwhile ideas might arise from the visitors' experiences in the museum, beyond those expected and planned?"

The museum visitor might be asked, "Why is this place important to you? How have you changed as a result of your experiences here? What do you hope to gain from a visit?"

Beyond the interests of pure research, these questions may have a practical payoff. For in answering these questions, visitors, museum educators, curators, administrators, and planners may be led to think more deeply about the meaning of their shared experiences. They may find that the meaning of their museum is basically metaphoric, that metaphor is a basic process of complex human thought, and that in their museum, beneath the surface of its everyday activities, lie infinite pools of meaning, a meaning that is strongly symbolic of essential human qualities.

\section{References}

Anderson, T. (1989). Interpreting works of art as social metaphors. Visual Arts Research, 15 (2), 42-51.

Black, M. (1981). Metaphor. In Johnson, M. (Ed.), Philosophical perspectives on metaphor. Minneapolis: University of Minnesota Press.

Campbell, J. (1986). The inner reaches of outer space: Metaphor as myth and as religion. New York: Alfred Van Der Marck.

Dewey, J. (1934). Art as experience. New York: Paragon Books.

Feinstein, H. (1982). Meaning and visual metaphor. Studies in Art Education, 23 (2).

Johnson, M. (Ed.), (1981). Philosophical perspectives on metaphor. Minneapolis: University of Minnesota Press.

Lakoff, G. \& Turner, M. (1989). More than cool reason. Chicago: University of Chicago Press.

Langer, S. (1957). Problems of art. New York: Charles Scribner's Sons. 
Levin, M.D. (19 ). The modern museum: Temple of showroom. Tel Aviv: Dvir.

MacDonald, S. \& Silverstone, R. (1990). Rewriting the museum's fictions: Taxonomies, stories, and readers. Cultural Studies, 4 (2), 176-89.

Patton, M. Q. (1990). Qualitative evaluation and research methods. (Second Edition). Newbury Park: Sage.

Postman, N.(1990, September/October). Museum as dialogue. Museum News.

Richards, I. A. (1981). The philosophy or rhetoric. In Johnson, M. (Ed.), Philosophical perspectives on metaphor. Minneapolis: University of Minnesota Press. 